\title{
SUITABILITY OF VARIOUS BUFFERS FOR GENOMIC DNA EXTRACTION OF PINEAPPLE (Ananas comosus) VAR. MD2
}

\author{
FIFI HAFIZZAH PENDI AND HASNAIN HUSSAIN* \\ Centre for Sago Research (CoSAR), Faculty of Resource Science and Technology, Universiti Malaysia Sarawak, 94300 Kota \\ Samarahan, Sarawak, Malaysia.
}

*Corresponding author: hhasnain@unimas.my

Submitted final draft: 6 May $2020 \quad$ Accepted: 12 May 2020

http://doi.org/10.46754/jssm.2020.12.008

\begin{abstract}
Methods for DNA extraction are of paramount importance to obtain high yield and high purity nucleic acids for molecular characterisation downstream. However, there is no specific extraction protocol developed for Ananas comosus var. MD2. Here, we compare the efficiency of five selected DNA extraction buffers which are extensively used for plant deoxyribonucleic acid (DNA) extraction with absence usage of phenol. The suitability of the extraction buffers was assessed based on both DNA yield and its quality. In this study, DNA extracts were quantified using ultraviolet (UV) spectrophotometry, spectrophotometric profiles and gel electrophoresis. Since interfering background substances are not visible in gel electrophoresis, examining PCR products of the crude DNA is recommended. To summarise, all the buffers yielded sufficient DNA of an approximate 50-200 $\mu \mathrm{g}$ from $1 \mathrm{~g}$ leaf tissue for downstream applications with different quality level. Out of five extraction methods, two give high yield and high-quality genomic DNA using Dellaporta-based method $(213.5 \mu \mathrm{g} / \mathrm{g})$ and Doyle \& Doyle-based method $(172.5 \mu \mathrm{g} / \mathrm{g})$. Among these extraction methods, the exclusion of detergents in extraction buffer served as the best extraction buffer for MD2 genomic DNA extraction. Also, from an economic point of view, the extraction buffer is cheaper compared to commercial DNA extraction kits.
\end{abstract}

Keywords: DNA extraction, Ananas comosus var. MD2, UV spectrophotometry, spectrophotometric profile, PCR.

\section{Introduction}

Molecular techniques and other downstream applications related to these techniques such as cloning, gene library construction and polymerase chain reaction (PCR) are powerful tools in the science field. The success of these downstream methods is strongly dependent on DNA extraction efficiency and the quality of the isolated DNA (Rana et al., 2019; Rawat et al., 2016). In addition, easy handling, timesaving and affordable extraction protocols are among the requirements in choosing extraction methods. In general, achieving high-quality DNA is essential for ensuring consistency in all subsequent steps in the analytical measurement process.

The isolation of high-quality DNA from plant tissue samples is relatively difficult compared to genomic DNA isolation from animal tissues (Abdel-Latif \& Osman, 2017; Anderson et al., 2018) due to the excessive presence of secondary metabolites and high polysaccharides content (El-Ashram et al., 2016). Contaminants such as polysaccharides resulted in handling difficulties (Abdel-Latif \& Osman, 2017) and also found to cause anomalous re-association kinetic (Murray \& Thompson, 1980). Thus, the presence of these compounds can severely affect the quality and quantity of the isolated DNA. Acid phenol is commonly used to eliminate protein from genomic DNA, however, phenol is omitted in this analysis as this reagent is highly toxic to both mankind and the environment (ElAshram et al., 2016; Rivero et al., 2006). In addition, Li et al. (2017) reported that phenol could significantly interfere with UV absorbance ratio quantitation by absorbing light in the range of 260 to $280 \mathrm{~nm}$. Besides that, working with phenol is labour-extensive as chloroform extraction is needed to remove phenol from the isolated DNA (Kasem et al., 2008). Apart from 
that, phenol is regarded as a PCR inhibitor as it can hinder PCR reaction even at a concentration of more than 0.2 percent (Anderson et al., 2018; Demeke \& Jenkins, 2010)

Over the years, a vast number of extraction methods were established. Most of the protocols established discussed the solutions and optimisation steps to overcome specific extraction problems, for example, high background contamination, low purity, low yield and high DNA shearing (Rana et al., 2019; Rawat et al., 2016). An excellent DNA extraction method must fulfil at least these four criteria: high quality of DNA which is presented by low shearing and high dsDNA portion, high purity of DNA which is indicated by the absence of smearing in agarose gel, high DNA yield and the crude DNA extracts must be able to be used as DNA template for PCR and other downstream processes (Kuhn et al., 2017). Meanwhile, commercial DNA extraction kits are viewed to be convenient in producing excellent DNA quality. However, the usage is viewed to be cost-intensive, particularly when involving high sample throughput or long sample campaign protocols.

Despite the vast number of pineapple studies conducted in the molecular biology field, there were limited $\mathrm{x}$ precise protocols in extracting pineapple plant genomic DNA. In this study, we compare different extraction buffers in terms of their yield amount and quality. The extracted DNA is then quantified using UV spectrophotometer followed by quantification via spectrophotometric profile (Beer-Lambert curve). The selected isolated DNA was further assessed for its applicability to RAPD and ISSR molecular markers. The research aims to determine the best extraction buffer for extracting MD2 genomic DNA based on the purity, quality and quantity of the isolated crude DNA. Therefore, through this study, the isolation protocol for MD2 pineapple and other pineapple variety crude DNA can be standardised for future genetic studies.

\section{Materials and Methods}

\section{Plant Samples}

The MD2 pineapple leaf samples were collected from the pineapple tissue culture research plot of CRAUN Research Sdn. Bhd., located at Kampung Mang in Kota Samarahan, Sarawak, Malaysia. Once harvested, the leaf samples were cleaned with tap water, dried and wrapped in a clean piece of tissue paper and kept in a zip-lock bag. The samples were stored in a Coleman $\mathbb{R}$ box filled with ice and stored in $-20^{\circ} \mathrm{C}$ until future use.

\section{Isolation of Genomic DNA}

Five DNA extraction buffers were used in this study (Table 1). The genomic DNA was extracted from the basal part of the pineapple leaf using a selected modified extraction technique (Borges et al., 2012) . For each extraction buffer examined, approximately $1 \mathrm{~g}$ of leaf sample was ground into fine powder in liquid nitrogen using mortar and pestle, followed by addition with $15 \mathrm{~mL}$ prewarmed $\left(65^{\circ} \mathrm{C}\right)$ extraction buffer. The mixture was vortexed for one minute and incubated in a water bath for $30 \mathrm{~min}$ at $65^{\circ} \mathrm{C}$ with intermittent mixing. After incubation, the mixture was left for five minutes to cool to room temperature and gently mixed with $15 \mathrm{~mL}$ chloroform-isoamyl alcohol (24:1). Next, the sample was subjected to centrifugation at $16,100 \mathrm{x}$ g for $15 \mathrm{~min}$ in a refrigerated centrifuge at $4^{\circ} \mathrm{C}$. The aqueous fraction formed following centrifugation was transferred into another sterile polypropylene tube and the DNA was precipitated using an equal volume of ice-cold isopropanol overnight at $-20^{\circ} \mathrm{C}$. Following overnight incubation, DNA pellet was collected by centrifugation at $16,100 \times \mathrm{g}$ for $15 \mathrm{~min}$ at $4^{\circ} \mathrm{C}$. The DNA pellet was dissolved in $1 \mathrm{~mL}$ of TE buffer $(10 \mathrm{mM}$ Tris HCL pH 8.0 and $1 \mathrm{mM}$ EDTA, $\mathrm{pH}$ 8.0) and transferred into a $1.5 \mathrm{~mL}$ microcentrifuge tube followed by centrifugation process at 16,100 $\mathrm{x} g$ for $15 \mathrm{~min}$ at $4^{\circ} \mathrm{C}$ for further pelleting out traces of viscous material and other impurities like polysaccharides. The aqueous fraction was precipitated again with one volume of ice-cold isopropanol for $1 \mathrm{hr}$ at $-20^{\circ} \mathrm{C}$. DNA pellet was 
collected by centrifugation at $16,100 \mathrm{~g}$ for 15 $\min$ at $4{ }^{\circ} \mathrm{C}$. The pellet was washed twice with 1 $\mathrm{mL} 70 \%$ cold ethanol, air-dried and resuspended in $100 \mathrm{~mL}$ TE buffer. An amount of $0.2 \mathrm{~mL}$ of RNase was added for RNA removal treatment. The DNA sample was stored in $-20^{\circ} \mathrm{C}$ for future use.

\section{DNA Quantification and Quality Control}

The quality and quantity of extracted MD2 genomic DNA samples were quantified using several assessment methods. First, the samples were quantified using a spectrophotometer (Eppendorf BioPhotometer D30, Germany). The crude DNA sample extracts were diluted by 50 dilution factors. Absorbance at $230 \mathrm{~nm}, 260$ $\mathrm{nm}, 280 \mathrm{~nm}$ and $340 \mathrm{~nm}$ and absorbance ratio at $260 / 230 \mathrm{~nm}$ and $260 / 280 \mathrm{~nm}$ were taken for each sample. DNA concentration obtained was determined using formula: $[\mathrm{DNA}]=\mathrm{A}_{260} \mathrm{x} \mathrm{DF}$ x $50 \mathrm{mg} / \mathrm{mL}$ where [DNA]; DNA concentration, $\mathrm{A}_{260}$; Absorbance at $260 \mathrm{~nm}$, DF; Dilution factor and $50 \mathrm{mg} / \mathrm{mL}$ refers to DNA concentration when $\mathrm{A}_{260}=1$ (Charlotte et al., 2016).

Second, the extracted genomic DNA samples were subjected to gel electrophoresis to determine possible degradation during the extraction process. A volume of $5 \mathrm{~mL}$ crude DNA extracts were run on $1 \%$ agarose gel containing $2 \mathrm{mg} / \mathrm{mL}$ of ethidium bromide (EtBr) under constant voltage of $90 \mathrm{~V}$ for $1 \mathrm{hr}$ using Owl Easycast B2 DNA Agarose Gel Electrophoresis Buffer Chamber (Thermo Scientific) and the resulting bands were visualised using UVP Benchtop UV Transilluminator.

\section{PCR Amplification}

Since PCR amplification is a common technique to assess crude DNA availability for further downstream application, we assessed the crude sample with RAPD primers and ISSR primers. The primer sequences are shown in (Table 2) (Kohpaii et al., 2017; Roostika et al., 2015). The PCR amplification was programmed as follows: initial denaturation at $94^{\circ} \mathrm{C}$ for $2 \mathrm{mn}$, followed by 45 cycles of denaturation at $94^{\circ} \mathrm{C}$ for $45 \mathrm{~s}$, annealing for $30 \mathrm{~s}$, an extension at $72^{\circ} \mathrm{C}$ for $2 \mathrm{~min}$ and the final extension at $72^{\circ} \mathrm{C}$ for $5 \mathrm{~min}$. The annealing temperature was based on the primer sequence listed in Table 2. The PCR products were then visualised by running $3 \mathrm{~mL}$ of each PCR product on $1 \%$ agarose gel containing EtBr. $1 \mathrm{~kb}$ DNA ladder (Thermo Scientific, Germany) was used as a marker.

Table 1: Extraction buffers and their components according to the authors

\begin{tabular}{|c|c|c|c|c|c|c|c|}
\hline \multirow[b]{2}{*}{$\begin{array}{l}\text { Extraction buffers } \\
\text { according to authors }\end{array}$} & \multicolumn{7}{|c|}{ Extraction buffer components } \\
\hline & Tris-HCl & $\mathrm{NaCl}$ & EDTA & $\beta$-me & CTAB & PVP & SDS \\
\hline $\begin{array}{l}\text { Doyle and Doyle (1987) } \\
\text { (Viana et al., 2015) }\end{array}$ & $\begin{array}{l}0.1 \mathrm{M} \\
(\mathrm{pH} 8.0)\end{array}$ & $1.25 \mathrm{M}$ & $\begin{array}{l}10 \mathrm{mM} \\
(\mathrm{pH} 8.0)\end{array}$ & $2 \%$ & $2 \%$ & $2 \%$ & - \\
\hline $\begin{array}{l}\text { Dellaporta et al. (1983) } \\
\text { (Dellaporta et al., 1983) }\end{array}$ & $\begin{array}{c}0.1 \mathrm{M} \\
(\mathrm{pH} 8.0)\end{array}$ & $0.5 \mathrm{M}$ & $\begin{array}{l}50 \mathrm{mM} \\
(\mathrm{pH} 8.0)\end{array}$ & $2 \%$ & - & - & - \\
\hline $\begin{array}{l}\text { Ferreira and Grattapaglia } \\
\text { (1998) (Viana et al., 2015) }\end{array}$ & $\begin{array}{c}0.1 \mathrm{M} \\
(\mathrm{pH} 8.0)\end{array}$ & $1.4 \mathrm{M}$ & $\begin{array}{l}20 \mathrm{mM} \\
(\mathrm{pH} 8.0)\end{array}$ & $2 \%$ & $2 \%$ & $1 \%$ & - \\
\hline $\begin{array}{l}\text { Edwards et al. (1991) } \\
\text { (Edwards et al., 1991) }\end{array}$ & $\begin{array}{c}0.2 \mathrm{M} \\
(\mathrm{pH} 8.0)\end{array}$ & $0.25 \mathrm{M}$ & $\begin{array}{l}25 \mathrm{mM} \\
(\mathrm{pH} 8.0)\end{array}$ & - & - & - & $0.5 \%$ \\
\hline $\begin{array}{l}\text { Taylor and Powell (1982) } \\
\text { (Randhawa, 2013) }\end{array}$ & $\begin{array}{l}0.05 \mathrm{M} \\
(\mathrm{pH} 8.0)\end{array}$ & $0.7 \mathrm{M}$ & $\begin{array}{l}10 \mathrm{mM} \\
(\mathrm{pH} 8.0)\end{array}$ & $0.1 \%$ & $1 \%$ & - & - \\
\hline
\end{tabular}


Table 2: Primers used to assess the availability of crude DNA sample as a template for PCR. amplification

\begin{tabular}{ccc}
\hline Primer & 5'-sequence-3' $^{\prime}$ & Annealing Temperature $\left({ }^{\circ} \mathbf{C}\right)$ \\
\hline OPA 3 & CACCGACTGA & 39.6 \\
OPA 16 & AAGCGACCGA & 43.7 \\
OPA 18 & TGCCAGTGGA & 42.4 \\
OPA 19 & GGCTGCAAAC & 40.6 \\
ISSR 1 & $(\mathrm{CA})_{7} \mathrm{AC}$ & 55.1 \\
ISSR 4 & $(\mathrm{GA})_{9} \mathrm{~T}$ & 55.8 \\
ISSR 6 & $(\mathrm{AG})_{7} \mathrm{~T}$ & 49.8 \\
ISSR 8 & $(\mathrm{GA})_{8} \mathrm{~T}$ & 52.4 \\
\hline
\end{tabular}

\section{Results and Discussion}

\section{DNA Quantification}

The extracted samples of MD2 genomic DNA were assessed for both of their quality and quantity. Prior to resuspension of DNA pellet in TE buffer, DNA pellet extracted using methods of Dellaporta et al. (1983), Edwards et al. (1991) and Taylor and Powell (1982) were observed to result in transparent pellets while others result in white opaque DNA pellet (results not shown). This observation implies that the isolated DNA is free from interfering contaminants such as polyphenols and polysaccharides (Ali et al., 2019; Gupta et al., 2020). The absorbance data taken from spectrophotometer provide an indication of sample purity and also their availability for PCR amplification and downstream sequencing. Our results showed that all the tested extraction buffers resulted in sufficient yield quantity for PCR amplification and downstream sequencing. The DNA purity obtained from crude DNA samples ranged from 1.69 to 1.97 , with extraction buffer from Dellaporta et al. (1983) scored the highest DNA purity (Table 3 ). The overall DNA concentration recorded ranged between $537.5 \mu \mathrm{g} / \mathrm{mL}$ to 2132.5 $\mu \mathrm{g} / \mathrm{mL}$ per one gram of plant sample. It was also noted that the DNA sample isolated scored the highest yield (at $2132.5 \mu \mathrm{g} / \mathrm{mL}$ ) among the buffers tested, using the extraction buffer from Dellaporta et al. (1983).

Table 3: The concentration of nucleic acid $(\mu \mathrm{g} / \mathrm{mL})$, DNA yield and absorbance readings. The absorbance reading was at $230 \mathrm{~nm}, 260 \mathrm{~nm}, 280 \mathrm{~nm}$, and $340 \mathrm{~nm}$. The absorbance ratio of 260/280 nm and 260/230 nm were used on the DNA sample for determination of purity

\begin{tabular}{ccccccccc}
\hline Extraction buffer & $\begin{array}{c}\text { Nucleic acid } \\
\text { concentration } \\
(\boldsymbol{\mu g} / \mathbf{m L})\end{array}$ & $\begin{array}{c}\text { DNA } \\
\mathbf{y i e l d} \\
(\boldsymbol{\mu g} / \mathbf{g})\end{array}$ & $\mathbf{A}_{230}$ & $\mathbf{A}_{260}$ & $\mathbf{A}_{280}$ & $\mathbf{A}_{340}$ & $\mathbf{A}_{260} / \mathbf{A}_{280}$ & $\mathbf{A}_{260} / \mathbf{A}_{230}$ \\
\hline Doyle and Doyle (1987) & 1725 & 172.5 & 0.484 & 0.690 & 0.374 & 0.009 & 1.87 & 1.43 \\
$\begin{array}{c}\text { Dellaporta } \text { et al. (1983) } \\
\begin{array}{c}\text { Ferreira and Grattapaglia } \\
\quad(1998)\end{array}\end{array}$ & 2132.5 & 213.25 & 0.378 & 0.853 & 0.430 & 0.008 & 1.97 & 2.25 \\
$\begin{array}{c}\text { Edwards } \text { et al. (1991) } \\
\text { Taylor and Powell (1982) }\end{array}$ & 1177.5 & 117.75 & 0.472 & 0.471 & 0.291 & 0.062 & 1.78 & 1.00 \\
\hline
\end{tabular}




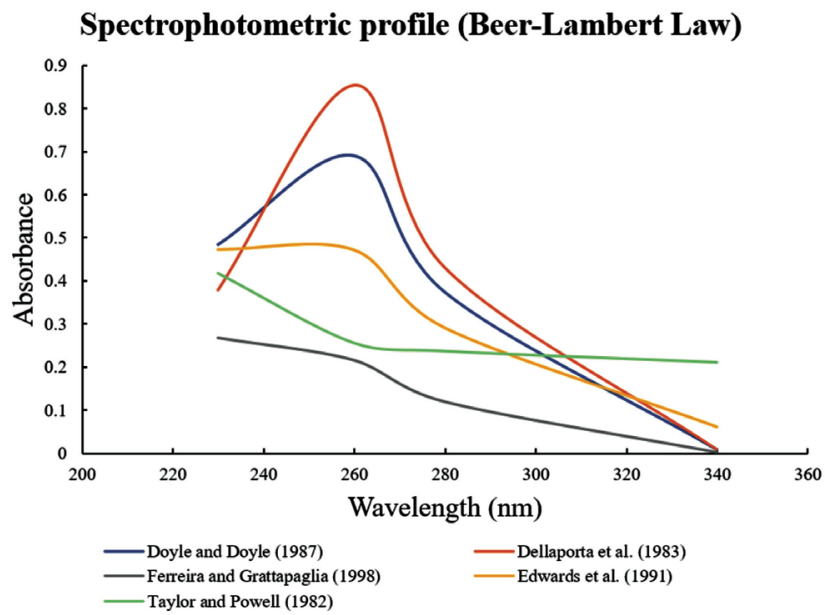

Figure 1: Spectrophotometric profile (Beer-Lambert) based on absorbance reading at 230, 260, 280, $340 \mathrm{~nm}$.

The absorbance wavelengths were employed for detection of chemical contaminations (e.g. Tris, EDTA), nucleic acid quantification, protein contamination and particulate matter respectively. The high-quality DNA showed a perfect hyperchromic shift with the highest peak absorbance at $260 \mathrm{~nm}$. DNA isolated using buffers mentioned in Doyle and Doyle (1987) and Dellaporta et al. (1983) showed a good quality of DNA

The crude DNA extracts were further quantified using the spectrophotometric profile (Beer-Lambert curve). Based on the BeerLambert curve plotted using the absorbance reading at $230 \mathrm{~nm}, 260 \mathrm{~nm}, 280 \mathrm{~nm}$ and $340 \mathrm{~nm}$, only spectrophotometric profiles from Doyle and Doyle (1987) and Dellaporta et al. (1983) follow the Beer-Lambert curve rules where maximum absorbance occurs at $260 \mathrm{~nm}$ (Figure 1).

\section{DNA Visualisation by Agarose Gel Electrophoresis and PCR Products}

All extracted DNA samples were further assessed for background substances and possible degradation during the isolation process. Through agarose gel electrophoresis, we observed that the DNA bands from all extracted samples have high molecular weights greater than the largest DNA fragment $(10 \mathrm{~kb})$ (Figure 2 ). The best quality of crude DNA sample was observed on Lane 2. The extracted DNA resulted in a distinct band without DNA shearing and minimal background impurities. Genomic DNA extract on Lanes 1 and 4 also gives a compact band but with some background. The bands on Lanes 3 and 5 appeared vague and less distinct with background impurities. The resulting crude genomic DNA obtained from modified Dellaporta et al. (1983) method was subjected to PCR amplification to test for its availability to the PCR technique. The resulting PCR products showed clear banding patterns (Figure 3).

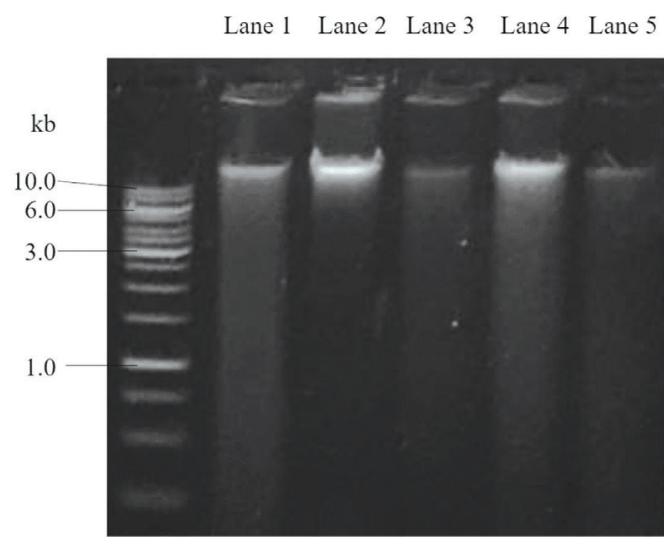

Figure 2: Genomic DNA isolated from MD2 pineapple leaves resolved in $1 \%$ agarose gel. Lane 1, Lane 2, Lane 3, Lane 4, Lane 5 show the isolated DNA using extraction buffer mentioned by Edwards et al. (1991), Dellaporta et al. (1983), Ferreira and Grattapaglia (1998), Doyle and Doyle (1987), and

Taylor and Powell (1982), respectively 


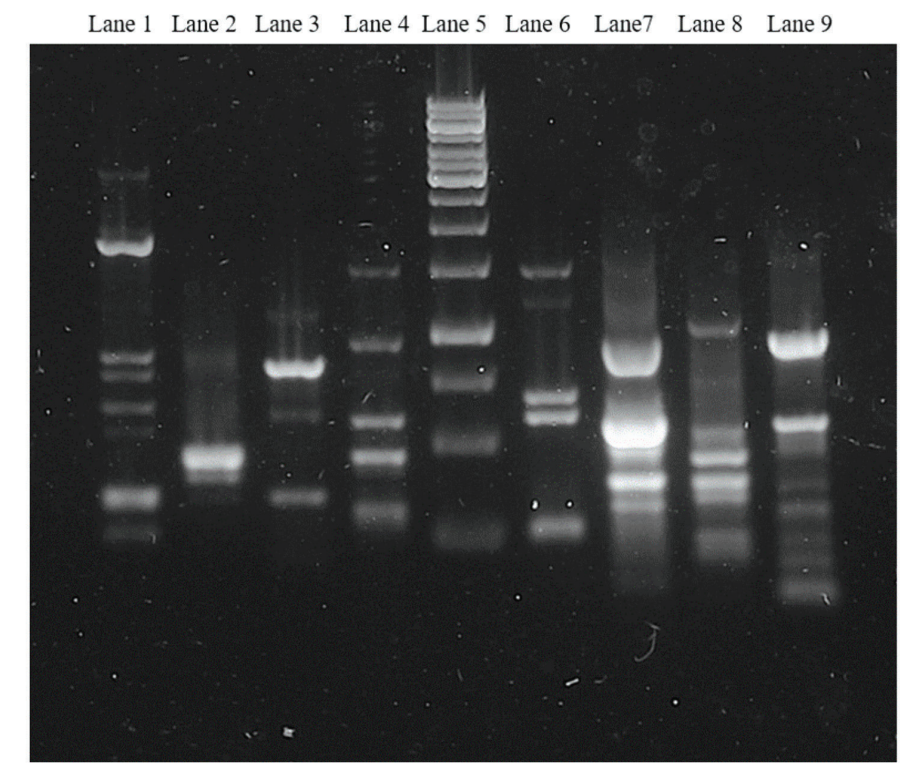

Figure 3: PCR products from modified Dellaporta et al. (1983) DNA sample; Agarose gel of $1 \%$ shows the PCR amplification of the representative primers. Lanes 1 to 4 RAPD primers: OPA 3, OPA 16, OPA 18, OPA 19, respectively; Lane $51 \mathrm{~kb}$ DNA ladder, Lanes 6 to 9 ISSR primers: ISSR 1, ISSR 4, ISSR 6, ISSR 8 , respectively

To the best of our knowledge, this paper is the first to compare different plant extraction buffers to extract MD2 pineapple DNA. A good extraction buffer depends heavily on overcoming complexities present in pineapple leaves. From this study, it was found extraction buffer (Dellaporta et al. (1983) is the best among the experimented buffers to extract pineapple DNA. The selection of the best extraction buffer for this study started with the quantification of the extracted crude DNA purity via absorbance ratio reading at 260/280 $\mathrm{nm}$. Most DNA samples extracted have absorbance ratio ${ }^{3} 1.8$ and lower than 2.0 except for DNA samples extracted using Edwards et al. (1991) and Taylor and Powell (1982) extraction buffers (Table 3). The resulting absorbance ratio suggests that the extracted DNA samples using extraction buffers, as suggested by Doyle and Doyle (1987), Dellaporta et al. (1983) and Ferreira and Grattapaglia (1998), were of high purity with the absence of proteins, salts or solvent contaminations and free from RNA contamination as well as DNA degradation (Abdel-Latif \& Osman, 2017; Borges et al., 2012).
It is common knowledge that purity quantification, using the absorbance ratio at $260 / 280 \mathrm{~nm}$, is a rapid and straightforward technique for routine usage. However, this technique is not the definitive measurement method for DNA purity due to non-robust properties of 260/280 $\mathrm{nm}$ in checking protein contamination in DNA extract solution as a consequence of strong light-absorbing properties of DNA at $260 \mathrm{~nm}$. On the other hand, the absorbance ratio is the definite purity quantification method in protein preparation to assess DNA and RNA contamination. Also, the $260 / 280 \mathrm{~nm}$ absorbance ratio is prone to give anomalous results for subsequent molecular research (Ahn et al., 1996). Thus, it is concluded that the absorbance ratio reading of $260 / 280 \mathrm{~nm}$ is not an adequate measure to determine DNA sample extracts' purity. Therefore, 260/230 nm ratio must be included as a secondary measure for nucleic acid purity quantification. Ideally, $260 / 230 \mathrm{~nm}$ absorbance ratio $>1.4$ or higher than the respective $260 / 280 \mathrm{~nm}$ absorbance ratio indicates pure sample (Boesenberg-Smith et al., 2012) whereas low $260 / 230 \mathrm{~nm}$ absorbance 
ratio of $<1.4 \mathrm{~nm}$ suggests the extracted sample contaminated by carbohydrates, salts or organic solvents (Kaeppler-Hanno, 2010). Our result shows that only DNA sample extracted using Dellaporta et al. (1983) extraction buffer has a higher 260/230 $\mathrm{nm}$ absorbance reading than its respective 260/280 $\mathrm{nm}$ absorbance ratio. This result is supported in (Singh et al., 2013) where the extraction of Dendrocalamus hamiltonii DNA using Dellaporta et al. (1983) was shown to have higher $260 / 230 \mathrm{~nm}$ ratio compared to its respective 260/280 nm with 2.41 and 1.83 absorbance ratio respectively.

A spectrophotometric profile (BeerLambert curve) is another evaluation method to determine DNA extracts purity. A doublestranded (ds) DNA has a maximum absorbance at $260 \mathrm{~nm}$ (Green \& Sambrook, 2018). Hence, a pure DNA extract will have a hyperchromic shift curve with the highest peak at $260 \mathrm{~nm}$. Apart from that, absorbance reading at several wavelengths $(230,260,280$ and $320 \mathrm{~nm})$ is compulsory as they act as the purity indicator (Green \& Sambrook, 2018). Referring to Figure 1, only Doyle and Doyle (1987) and Dellaporta et al. (1983) spectrophotometric profiles follow the Beer-Lambert curve rule with the maximum absorbance at $260 \mathrm{~nm}$. This suggests that the DNA samples are intact, dsDNA. The remaining extraction buffers did not result in proper hyperchromic shift graphs. The plotted graphs were found to have high absorbance reading at $230 \mathrm{~nm}$. Absorbance at $230 \mathrm{~nm}$ is an indicator to detect the presence of chemical contaminations such as Tris and EDTA and guanidine salt carryover level (Gerstein, 2004).

It is of enormous importance to test extracted DNA samples' quality and integrity. The result of this study showed that the DNA sample from Dellaporta et al. (1983) gave the best crude DNA sample quality (Figure 2). The DNA band appears of high molecular weight and has low shear damages and low impurity content. Other genomic extracts are viewed to have some background hence suggesting degradation or containing impurities or both (Abdel-Latif \& Osman, 2017; Kumari et al., 2012). Also, the observed backgrounds were consistent with the $260 / 230 \mathrm{~nm}$ absorbance ratio with $<2.0$, indicating the DNA samples were contaminated by carbohydrates, salts or organic solvents (Kaeppler-Hanno, 2010). The resulting vague bands observed in Lanes 3 and 5 indicate a very low DNA concentration in crude DNA solution. This observation is in line with a very low DNA yield obtained through Ferreira and Grattapaglia (1998) $(53.75 \mu \mathrm{g} / \mathrm{g})$ and Taylor and Powell (1982) $(63.75 \mu \mathrm{g} / \mathrm{g})$ isolation buffer. Assessing DNA sample's integrity is crucial especially applying DNA sample for further downstream molecular techniques as any damage on the DNA strands may result in unamplified gene region during the PCR (Mcllroy et al. (2009) cited by Kuhn et al. (2017)). Besides, the context of checking crude DNA through agarose gel visualisation can be misleading. A combination procedure of agarose gel and PCR amplification is recommended for further verification of the DNA quality. This is because structural damages of DNA or/ and DNA containing impurities such as tannins, alkaloid and polyphenols can result in failed PCR amplification (AbdelLatif \& Osman, 2017; Kuhn et al., 2017). For example, in the work of (Kuhn et al., 2017) the crude DNA extract obtained using the protocol recommended by (Wilson, 2001) failed PCR amplification and thus supported gel smearing and DNA fragmentation observed in agarose gel to be of lower integrity quality. Due to the excellent quality of DNA band visualised from Dellaporta et al. (1983), the DNA sample was introduced to PCR amplification using RAPDs and ISSRs primers to test for its integrity. The PCR products (Figure 3) showed bright and clear banding patterns for both molecular markers suggesting the purity of extracted DNA was excellent as evidenced by the $260 / 280 \mathrm{~nm}$ ratio of 1.97 and $260 / 230 \mathrm{~nm}$ ratio of $>2.0$. In addition, the amplification has also indicated the genomic preparations were free from Taq polymerase inhibitors and the absence of genomic structural damage.

The composition of all the examined extracted buffers was simple, and the protocol used excludes expensive or exclusive chemicals 
and the usage of commercial kits/column material. In this experiment, all the experimented extraction buffers were supplemented with detergents except in modified Dellaporta et al. (1983) extraction buffer. In spite of detergentbased extraction buffer is frequently applied in DNA isolation techniques, buffers supplemented with detergents in this experiment failed to give a better result in the context of DNA quality, though able to produce a reasonable amount of DNA yield. As depicted in Table 2 and Figure 2, the study concludes that the DNA extraction method based on Dellaporta et al. (1983) has resulted in the highest DNA yield per gram sample with $213.25 \mu \mathrm{g}$ and given a compact DNA band with low background impurities. DNA isolations of potato (S. tuberosum L.), Brassica sp., oilseed and Jatropha crops have been found to produce DNA of high quality with an absorbance ratio of 260/280 nm between 1.70 and 1.90 with DNA yield between 70 and $120 \mu \mathrm{g} / \mathrm{g}$ leaf (Kumari et al., 2012). In contrast to detergent-based protocols, DNA quality and yield were found to be lower. This can be observed in babassu palm DNA isolation work using Dellaporta et al. (1983) supplemented with SDS detergent where the 260/280 $\mathrm{nm}$ absorbance ratio was 1.63 with a lower DNA concentration of 70.10 $\mathrm{ng} / \mu \mathrm{L}$ (Viana et al., 2015). Also, the inclusion of PVP in the lysis buffer did not result in any significant improvement in the yield or purity of DNA (Kumari et al., 2012) as seen in the work of DNA isolation from chrysanthemum seeds where it resulted in a decrease of DNA yield compared to isolation without PVP (Sudan et al., 2017).

A few tips and techniques were implemented to ensure a successful DNA extraction from plant samples. In this work, the tissue samples were ground into a very fine powder in liquid nitrogen. The grinding process helps to break down cell walls and increases the surface ratio of the tissue sample to enhance tissue interactions with the isolation buffer. This step is crucial to obtain high DNA yield. This observation is supported by another study where it was reported that inefficient grinding generally resulted in low DNA yields (Anderson et al., 2018). Furthermore, the usage of liquid nitrogen facilitates the grinding process as the latter abruptly converts tissues into brittle solid (Kasajima, 2018) and also keeps the cellular enzymes deactivated to prevent shearing and damage to DNA structure (Aboul-Maaty \& Oraby, 2019). The addition of pre-warmed isolation buffers further break sample tissue as the high temperature at $60-70^{\circ} \mathrm{C}$ provides a favourable environment for components in the buffer to work better hence enhances the recovery of high-quality DNA (Hanjalić et al., 2018; Sudan et al., 2017). The vigorous vortexing prior to the incubation in the water bath is significant to allow further mixing of tissue with isolation buffer (Sudan et al., 2017). As for the incubation period in the water bath, it is vital to not exceed the suggested 30 minute-duration because a more extended period will lead to DNA degradation. Intermittent tube inverting during incubation in a water bath was to mix tissue samples further as they commonly settled at the bottom of the tube (Sudan et al., 2017). While transferring the aqueous supernatant after centrifugation step, it is recommended to use wide-bore tips pipettes to prevent genomic DNA shearing (Ali et al., 2019; Anderson et al., 2018; Kasajima, 2018). The step, in which pellet washing was done twice with $70 \%$ ethanol, was to ensure complete removal traces of salt and alcohol (Osena et al., 2017).

In this study, all the tested isolation buffers were supplemented with detergents like CTAB, SDS and PVP except in the modified Dellaporta et al. (1983) extraction buffer. Despite the importance of detergents in cell lysis, the modified Dellaporta et al. (1983) supplemented a high amount of ethylenediaminetetraacetic acid (EDTA) of $50 \mathrm{mM}$ concentration to replace detergent action in disrupting the cell walls and nuclear membrane to expose genetic components to the buffer solution. The potential action of EDTA to sequester metal ions such as $\mathrm{Mg}^{2+}$ and $\mathrm{Ca}^{2+}$ from cellular membranes when applied to pulverized plant tissues during incubation at higher temperature can help in plant cell lysis hence suggesting EDTA to be considered as a substitute for detergent (Kumari et al., 2012). In 
addition, the high affinity of EDTA to divalent cations such as $\mathrm{Ca}^{2+}, \mathrm{Mn}^{2+}$ and $\mathrm{Mg}^{2+}$ acts as the co-factors in preventing endogenous nucleases activities (Adams et al., 1992; Osena et al., 2017; Rosenberg, 1987; Tiwari et al., 2017; Yu et al., 2017). Furthermore, the interaction of Tris hydrochloride (Tris-HCl), EDTA complex and the reducing agent beta-mercaptoethanol (bme) with the outer membrane polysaccharides helps to destabilise cell membrane and further breaks down the cell during cell lysis (Green \& Sambrook, 2018; Varma et al., 2007).

All extraction buffers were supplemented with $\mathrm{NaCl}$ to eliminate polysaccharides. The concentration of $\mathrm{NaCl}$ varied with plant sample species in a range between $0.7 \mathrm{M}$ (Clark, 1997) to $6 \mathrm{M}$ (Aboul-Maaty \& Oraby, 2019; Aljanabi et al., 1999). In contrast, $\mathrm{NaCl}$ concentration of $1.5 \mathrm{M}$ or $2.0 \mathrm{M}$ is sufficient to remove high polysaccharide content in DNA sample (Fang et al., 1992; Yu et al., 2017). In the present study, the low amount of $\mathrm{NaCl}(0.5 \mathrm{M})$ in the modified Dellaporta et al. (1983) extraction buffer was found to be sufficient to improve the quality of the extracted DNA sample compared to other extraction buffers supplemented with other $\mathrm{NaCl}$ concentrations. Commonly, phenol: chloroform: isoamyl alcohol (25:24:1) (PCI) are used in many plant DNA extraction to eliminate proteins, tannins and polyphenols. In contrast to our work, phenol is excluded due to its hazardous property and replaced with chloroform: isoamyl alcohol (24:1) and of b-me. The presence of b-me antioxidant properties allow chloroform: isoamyl alcohol to further eliminate proteins from DNA (Hanjalić et al., 2018) and weaken the disulfide bonding between cysteine residues to remove tannins and polyphenols (Yu et al., 2017). Furthermore, phenol-using protocols are typically go to denaturing step twice with phenol, then chloroform: isoamyl alcohol. This additional move will, therefore, result in further depletion of DNA yield (Gupta et al., 2020).

To ensure comparability between extraction buffers, the use of fresh and young leaf materials is recommended. Previous research used young leaves to extract DNA due to lower content of polysaccharides, polyphenols and other secondary metabolites content (Sharmin et al., 2018; Shukla et al., 2016; Sinha \& Kumar, 2017; Sugita et al., 2019). Based on our experience, the use of the young basal leaf section in all protocols has been found to result in a very light yellow to translucent supernatant following the addition of chloroform: isoamyl alcohol after centrifugation process compared to utilising older/mature leaf part (picture not shown here), hence suggesting that low secondary compounds are present in the younger leaf. In contrast, old/mature leaves give results in yellowish to dark brown supernatant (Zigene et al., 2019). Therefore, it is concluded that the use of young plant materials further helps in obtaining highquality DNA.

The modified Dellaporta et al. (1983) extraction buffer proves to be the most suitable for extracting MD2 pineapple DNA sample. From our result, there was no DNA degradation detected during isolation with minimal background smearing and thus further substantiates purity of the extracted DNA sample. Previous works suggested that any shearing of DNA during extraction procedure can interfere directly or indirectly with enzymatic reactions during other molecular studies (Aljanabi et al., 1999). The resulting PCR amplification suggests that extracted DNA did not contain any impurities which can inhibit the Taq DNA polymerase activity. In conclusion, the modified Dellaporta et al. (1983) extraction buffer is the best for use in DNA extraction of MD2 pineapple plants.

\section{Conclusion}

The modified Dellaporta et al. (1983) extraction buffer can be used for extracting MD2 pineapple genomic DNA. Elimination usage of hazardous phenol and detergent in the extraction buffer results in high quality and high-yielding genomic DNA. The resulting DNA is also amendable to both RAPD and ISSR amplifications. Therefore, this finding is highly recommended for DNA extraction from MD2 pineapple, and the sample preparation is suitable for various molecular analytical techniques. 


\section{Acknowledgements}

The authors are grateful to UNIMAS Tun Openg Sago Chair Research Grant F07/ TOC/1743/2018, awarded to HH for funding of this research. FHP thanked Universiti Malaysia Sarawak for the UNIMAS ZSU-ESSU scholarship. The authors would like to thank Dr Bala Jamel form CRAUN Research Sdn. Bhd., Kuching, Sarawak for providing the pineapple samples used in this study.

\section{References}

Abdel-Latif, A., \& Osman, G. (2017). Comparison of three genomic DNA extraction methods to obtain high DNA quality from maize. Plant Methods, 13(1), 1.

Aboul-Maaty, N. A. F., \& Oraby, H. A. S. (2019). Extraction of high-quality genomic DNA from different plant orders applying a modified CTAB-based method. Bulletin of the National Research Centre, 43(25), 1-10.

Adams, R. L. P., Knowler, J. T., \& Leader, D. P. (1992). The biochemistry of nucleic acids. Chapman and Hall, London, New York.

Ahn, S. J., Costa, J., \& Emanuel, J. R. (1996). PicoGreen quantitation of DNA: effective evaluation of samples pre- or post-PCR. Nucleic Acids Research, 24(13), 2623-5.

Ali, Q., Salisu, I. B., Raza, A., Shahid, A. A., Rao, A. Q., \& Husnain, T. (2019). A modified protocol for rapid DNA isolation from cotton (Gossypium spp.). Methods X, 6, 259264.

Aljanabi, S. M., Forget, L., \& Dookun, A. (1999). An improved and rapid protocol for the isolation of polysaccharide and polyphenol free sugarcane DNA. Plant Molecular Biology Reporter, 17(3), 281-282.

Anderson, C. B., Franzmayr, B. K., Hong, S. W., Larking, A. C., Van Stijn, T. C., Tan, R., Moraga, R., Faville, M. J., \& Griffiths, A. G. (2018). Protocol: a versatile, inexpensive, high-throughput plant genomic DNA extraction method suitable for genotypingby-sequencing. Plant Methods, 14(75),
$1-10$.

Boesenberg-Smith, K. A., Pessarakli, M. M., \& Wolk, D. M. (2012). Assessment of DNA yield and purity: an overlooked detail of PCR troubleshooting. Clinical Microbiology Newsletter, 34(1), 3-6.

Borges, D. B., Amorim, M. B., Waldschmidt, A. M., Mariano-Neto, E., Vivas, C. V., \& Pereira, D. G. (2012). Optimization of DNA extraction from fresh leaf tissues of Melanoxylon brauna (Fabaceae). Genetics and Molecular Research, 11(2), 1586-1591.

Clark, M. S. (1997). Plant molecular biology-a laboratory manual. Springer, Berlin, Germany.

Dellaporta, S. L., Wood, J. A., \& Hicks, J. B. (1983). A plant DNA minipreparation: version II. Plant Molecular Biology Reporter, 1(4), 19-21.

Demeke, T., \& Jenkins, G. R. (2010). Influence of DNA extraction methods, PCR inhibitors and quantification methods on real-time PCR assay of biotechnology-derived traits. Analytical and Bioanalytical Chemistry, 396, 1977-1990.

Doyle, J. J., \& Doyle, J. L. (1987). A rapid DNA isolation procedure for small quantities of fresh leaf tissue. Phytochemical Bulletin, 19, 11-15.

Edwards, K., Johnstone, C., \& Thompson, C. (1991). A simple and rapid method for the preparation of plant genomic DNA for PCR analysis. Nucleic Acids Research, 19(6), 1349.

El-Ashram, S., Al Nasr, I., \& Suo, X. (2016). Nucleic acid protocols: Extraction and optimization. Biotechnology Reports, 12, 3339.

Fang, G., Hammar, S., \& Grumet, R. (1992). A quick and inexpensive method for removing polysaccharides from plant genomic DNA. BioTechniques, 13(1), 52-54.

Ferreira, M. E., \& Grattapaglia, D. (1998). Introdução ao uso de marcadores moleculares em análise genética (Tr. Introduction 
to the use of molecular markers in genetic analysis). 3rd. ed. EMBRAPA-Cenargen, Brasilia, Brazil.

Gerstein, A. S. (2004). Molecular Biology Problem Solver: A Laboratory Guide. John Wiley \& Sons, New York, USA.

Green, M. R., \& Sambrook, J. (2018). Isolation and Quantification of DNA. Cold Spring Harbor Protocols, 2018(6), pdb.top093336.

Gupta, P., Salava, H., Sreelakshmi, Y., \& Sharma, R. (2020). A low-cost high-throughput method for plant genomic DNA isolation. In: Cereal Genomics: Methods and Protocols, (Ed.) L. Vaschetto, Vol. 2072, Humana Press. New York, pp. 1-8.

Hanjalić, J., Lasić, L., Gaši, F., Meland, M., Grahic, J., \& Stroil, B.K. (2018). The applicability of three DNA isolation methods in SSR analysis of hexaploid plum (Prunus domestica L.) cultivars. Genetics and Applications, 2(1), 1-7.

Kaeppler-Hanno, K. (2010). Troubleshooting guide for the measurement of nucleic acids with the BioPhotometer plus. In: Userguide No 13, Eppendorf. Hamburg, Germany.

Kasajima, I. (2018). Successful tips of DNA extraction and PCR of plants for beginners. Trends in Research, 1(3), 1-6.

Kasem, S., Rice, N., \& Henry, R. J. (2008). DNA extraction from plant tissue. In: Plant Genotyping II: SNP Technology, (Ed.) R. J. Henry, CABI. London, pp. 219-271.

Kohpaii, F. N., Farahani, F., \& Noormohammadi, Z. (2017). Somaclonal variation in the in vitro regenerated pineapple (Ananas comosus): investigation of the cellular characteristics, biochemical specificities and ISSR markers. Phytologia Balcanica, 23(1), 7383.

Kuhn, R., Böllmann, J., Krahl, K., Bryant, I. M., \& Martienssen, M. (2017). Comparison of ten different DNA extraction procedures with respect to their suitability for environmental samples. Journal of Microbiological Methods, 143, 78-86.
Kumari, V., Bansal, A., Aminedi, R., Taneja, D., \& Das, N. (2012). Simplified Extraction of Good Quality Genomic DNA from a Variety of Plant Materials. African Journal of Biotechnology, 11(24), 6420-6427.

Li, X., Kanakala, S., He, Y., Zhong, X., Yu, S., Li, R., Sun, L., \& Ma, J. (2017). Physiological characterization and comparative transcriptome analysis of white and green leaves of Ananas comosus var. bracteatus. PloS One, 12(1), 1-17.

McIlroy, S. J., Porter, K., Seviour, R. J., \& Tillett, D. (2009). Extracting nucleic acids from activated sludge which reflect community population diversity. Antonie van Leeuwenhoek, 96(4), 593.

Murray, M. G., \& Thompson, W. F. (1980). Rapid isolation of high molecular weight plant DNA. Nucleic Acids Research, 8(19), 4321-4326.

Osena, G., Nyaboga, E. N., \& Amugune, N. O. (2017). Rapid and efficient isolation of high quality DNA from cassava (Manihot esculenta Crantz) suitable for PCR based downstream applications. Annual Research \& Review in Biology, 12(2), 1-10.

Rana, M. M., Aycan, M., Takamatsu, T., Kaneko, K., Mitsui, T., \& Itoh, K. (2019). Optimized nuclear pellet method for extracting nextgeneration sequencing quality genomic DNA from fresh leaf tissue. Methods and Protocols, 2(54), 1-11.

Rawat, S., Joshi, G., Annapurna, D., Arunkumar, A. N., \& Karaba, N. N. (2016). Standardization of DNA extraction method form mature dried leaves and ISSR-PCR conditions for Melia dubia Cav.- a fast growing multipurpose tree species. American Journal of Plant Sciences, 7, 437-445.

Rivero, E. R. C., Neves, A. C., Silva-Valenzuela, M. G., Sousa, S. O. M., \& Nunes, F. D. (2006). Simple salting-out method for DNA extraction from formalin-fixed, paraffinembedded tissues. Pathology-Research and Practise, 202, 523-529. 
Roostika, I., Khumaida, N., \& Ardie, S. W. (2015). RAPD analysis to detect somaclonal variation of pineapple in vitro cultures during micropropagation. Biotropia, 22(2), 109-119.

Rosenberg, N.L. 1987. ATP as an alternative inhibitor of bacterial and endogenous nucleases and its effect on native chromatin compaction. Molecular and Cellular Biochemistry, 76(2), 113-121.

Sharmin, A., Hosque, M. E., Haque, M. M., $\&$ Khatun, F. (2018). Molecular diversity analysis of some chili (Capsicum spp.) genotypes using SSR markers. American Journal of Plant Sciences, 9(3), 368-379.

Shukla, R., Sharma, D. C., Pathak, N., \& Bajpai, P. (2016). Genomic DNA isolation from high polyphenolic content Grewia asiatica L. leaf without using liquid nitrogen. Iranian Journal of Science and Technology, Transaction A: Science, 42(2), 347-351.

Singh, S. R., Dalal, S., Singh, F., Dhawan, A. K., \& Kalia, R. K. (2013). Molecular profiling of Dendrocalamus asper and D. Hamiltoni using RAPD, ISSR and SSR markers-effects of DNA extraction methods on PCR amplification. Indian Forester, 139(11), 969-977.

Sinha, S., \& Kumar, A. (2017). Evaluation of economical and rapid method of plant DNA extraction for PCR analysis of different crops. Journal of Applied and Natural Science, 9(2), 866-870.

Sudan, J., Raina, M., Singh, R., Mustafiz, A., \& Kumari, S. (2017). A modified protocol for high-quality DNA extraction from seeds rich in secondary compounds. Journal of Crop Improvement, 31(5), 637-647.
Sugita, N., Ehihara, A., Hosoya, T., Jinbo, U., Kaneko, S., Kurosawa, T., Nakae, M., \& Yukawa, T. (2019). Non-destructive DNA extraction from herbarium specimens: a method particularly suitable for plants with small and fragile leaves. Journal of Plant Research, 133(1), 133-141.

Taylor, B., \& Powell, A. (1982). Isolation of plant DNA and RNA. BRL Focus, 4(3), 4-6.

Tiwari, S., Tomar, R.S., Tripathi, M.K., \& Ahuja, A. (2017). Modified protocol for plant genomic DNA isolation. Indian Research Journal of Genetics and Biotechnology, 9(4), 478485 .

Varma, A., Padh, H., \& Shrivastava, N. (2007). Plant genomic DNA isolation: An art or a science. Biotechnology Journal, 2(3), 386392.

Viana, J. P., Borges, A. N., Lopes, A. C., Gomes, R. L., Britto, F. B., Lima, P. S., \& Valente, S. E. (2015). Comparison of eight methods of genomic DNA extraction from babassu. Genetics and Molecular Research, 14(4), 18003-8.

Wilson, K. (2001). Preparation of genomic DNA from bacteria. Current Protocols in Molecular Biology, 56, 2.4.1-2.4.5.

Yu, G., Hatta, A., Periyannan, S., Lagudah, E., \& Wulf, B. B. (2017). Isolation of wheat genomic DNA for gene mapping and cloning. In: Wheat rust diseases: methods and protocols, methods in molecular biology, Humana Press. New York, pp. 207-213.

Zigene, Z. D., Asfaw, B. T., \& Bitima, T. D. (2019). Optimizing DNA isolation protocol for rosemary (Rosemarinus officinalis L) accessions. African Journal of Biotechnology, 18(30), 895-900. 